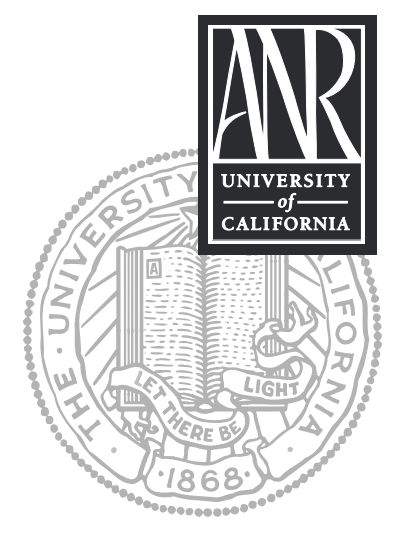

UNIVERSITY OF CALIFORNIA

Division of Agriculture and Natural Resources http://anrcatalog.ucdavis.edu

\title{
FOREST STEWARDSHIP SERIES 6 Forest Vegetation Management
}

\author{
CLARALYNN NUNAMAKER, California Registered Professional Forester, Scotland, UK; \\ YANA VALACHOVIC, UCCE Forest Advisor, Humboldt and Del Norte Counties
}

There is both an art and a science to forest stewardship. At the core of stewardship is the management of vegetation, which includes management of young and old trees, shrubs, and herbaceous plants. Whether your goals are to manage for an economic return from timber harvesting, maintain or enhance wildlife habitat, improve aesthetics, restore the forest, maintain a certain stand characteristic, or recover from a specific event such as a wildfire, wind, or ice storm, it is important to understand how different vegetation management strategies can help accomplish your goals. In the field of forestry, vegetation management is generally called silviculture.

\section{Objective}

Understand how forest vegetation can be managed to achieve your goals and objectives.

\section{Competencies}

- Understand that landowners have the responsibility to protect and maintain public trust resources.

- Observe how "letting nature take its course" can produce many unintended consequences.

- Become familiar with silviculture: the art and science of producing, tending, and harvesting a forest.

- Learn that choosing a silvicultural system for your forest requires understanding the advantages and disadvantages peculiar to each system and how they relate to your goals and site conditions.

- Realize that the more clearly you can define and describe your goals and objectives, the more likely that you will be satisfied with your forest after a harvest.

- Discover the variety of cost-share programs that may be available to help you fund forest management and restoration projects.

\section{Related Forest Stewardship Series Publications}

- Forest Ecology, ANR Publication 8233

- Forest History, ANR Publication 8234

- Tree Growth and Competition, ANR Publication 8235

- Forest Regeneration, ANR Publication 8237

- Stewardship Objectives and Planning, ANR Publication 8248

- Laws and Regulations Affecting Forests, Part l: Timber Harvesting, ANR Publication 8249

- Economic Considerations in Forest Stewardship, ANR Publication 8251

- Technical and Financial Assistance, ANR Publication 8253

- Professional Assistance, ANR Publication 8254

\section{PUBLIC TRUST RESOURCES}

Even though land may be privately owned, managing natural resources requires an understanding of your responsibility to protect "public trust" resources. These resources are protected for the benefit of the people of the state. Public trust resources include (but are not limited to) air and water quality, wildlife, and certain environmental resources such as tidelands and wetlands. Many laws apply to natural resource management on private lands to ensure that these public trust resources are not degraded. As a result of these laws, certain vegetation management activities are either prohibited or restricted. Protection of public trust resources, for example, is the principle underlying the Forest Practice Act and the regulations of the state and regional water quality control boards that aim to protect water quality and the beneficial uses of water while allowing timber harvesting or forest management.

\section{STYLES OF MANAGEMENT}

Trees grow and die with or without our management, but the number of trees on every acre and the ratio of live trees versus dead trees can be influenced by management. Some people may consider that the best strategy is to let nature run its course and not decide which trees should survive or regenerate. This style of management is "passive," in contrast to an "active" style that seeks to directly influence forest stand density and health. Although in the short run, letting nature take its course may seem to have few adverse consequences, in the long term it can have profound effects on a forest. This is because the natural processes themselves have already been altered at scales 
well beyond a single forest property. Many people are beginning to recognize that because of years of fire suppression and passive forest management, many forests have become overly dense. This has resulted in stressed trees, disease outbreaks, and dominance of tree species that reproduce in crowded, shaded conditions. California's forest evolved with and depended on fire to keep the forests healthy and diverse. Changes in vegetation and wildfire risk due to fire suppression have radically affected millions of acres of forestland in California, and the frequency, intensity, and scale of natural fires have changed as a result. Safely restoring natural fire processes to a single property or an entire landscape requires active management. In the absence of fire, it is possible to thin trees to reduce competition and create openings so that shade-intolerant or sunrequiring tree species can grow. Another example of altered processes concerns invasive plants. Without active management, a landowner may stand by and watch streams, fields, and forests become overwhelmed by aggressive exotic plants.

This publication presents active management methods that can be used to effectively develop desired forest conditions. Be aware that although these methods have proven useful, applying them to your forest should be considered to be an experiment. Many landowners develop their own personalized approach to vegetation management after years of trial and error. Consider the methods provided here as conceptual approaches to be refined and modified for application to your specific forest and management objectives. While the majority of information presented here relates to forest management that may lead to commercial harvest, the vegetation management concepts apply equally to noncommercial or restoration activities.

\section{SILVICULTURAL SYSTEMS AND METHODS}

If your management style is active, you are probably already practicing silviculturethe science and art of producing, tending, and harvesting a forest. A silvicultural system is the plan of treatments for a forest stand over its entire life, including the establishment of a new stand after harvest.

Silvicultural systems are named on the basis of the number of age classes in the forest (one or two to several) and the method used to regenerate (or establish and grow) the forest. "Even-aged" silvicultural systems use clear-cutting or reserve a limited number of "seed" or "shelterwood" trees to achieve the establishment of new seedlings. Clear-cut areas are commonly planted with seedlings, while seed tree and shelterwood areas are usually expected to regenerate naturally. Both yield a new stand of trees that are all the same age or a two-storied stand of seed trees and seedlings (after successful establishment of seedlings, seed or shelterwood trees are commonly removed). In contrast, "uneven-aged" systems generally use harvesting of individual trees or groups of trees to develop a number of age classes in the forest. These systems may seek to maintain continuous mature forest cover while allowing for some regeneration. These systems are based on the method of regeneration and include associated treatments for different stages of stand development, such as thinning, pruning, and managing competing vegetation.

Silvicultural systems should be chosen on the basis of forest type, site conditions, and management objectives. The legally permitted systems in California are described below. The chosen system must be adapted for application to a specific property. In many cases, especially on larger properties, a mixture of silvicultural systems will be used.

Any entry into a forest stand with heavy equipment can cause long-term damage if reasonable protective practices are ignored. This discussion assumes that silvicultural systems are designed and executed properly, with full consideration for local conditions. 


\section{Even-aged Management}

"Even-aged" is not a very descriptive term for the results obtained from clear-cutting, seed tree, or shelterwood harvesting. In a given even-aged stand, after harvest and regeneration, the trees will be roughly the same age and size. But, over a large property or landscape, numerous sites may be harvested at different times to create a multitude of age classes in the forest. Clear-cut harvest units cannot exceed 20 acres (about 8 ha) in California, and harvest units retaining seed or shelterwood trees are also limited in size.

\section{Clear-cutting}

In clear-cutting, all or most of the trees in a stand are cut at the same time (fig. 1). The average stand age before harvest may be 60 to 80 years, depending on the productivity of the site and the forest type. Nursery-grown (planted) seedlings are generally used to regenerate the stand, though seeds from surrounding trees or the sprouts from stumps, as in the case in redwood, may be relied upon.

Clear-cutting provides an open environment that is most suitable for the establishment and subsequent growth of species that are intolerant of shade. However, on harsh sites (such as those with limited water availability, thin soils, or south-facing aspects), clear-cutting can create conditions that planted seedlings are incapable of surviving. After harvest, clear-cut sites are commonly prepared for planting by either broadcast-burning debris and slash or by piling and burning.

Clear-cutting changes wildlife habitat. The habitat that is created after planting depends on whether shrubs and herbaceous species populate the site, whether and how they are controlled to reduce competition with seedlings, how fast the planted seedlings grow, and other factors. As a general rule, clear-cutting creates early-successional habitats that are suitable for wildlife such as deer and elk that use grass, herbaceous, and shrub food sources. Other species such as rabbits and gophers that can have negative effects on seedlings may also benefit from the habitat created. As the new stand matures, the habitat will change, and the wildlife species and their use patterns will change as well. For example, a recent clear-cut may provide food sources for deer, while the same stand after 10 or 20 years stand may provide deer with cover and breeding habitat.

As with all silvicultural systems, clear-cutting has its advantages and disadvantages. One great disadvantage is the appearance of a recent clear-cut. The forest changes abruptly from a mature stand to a very young one, and logging debris is usually evident. Other potential disadvantages include negative impacts on wildlife habitat and potential soil erosion. A major emphasis in the review of timber harvest plans (THPs, the permit used to commercially harvest trees in California) that propose clear-cutting is to minimize or mitigate these and other potential impacts.

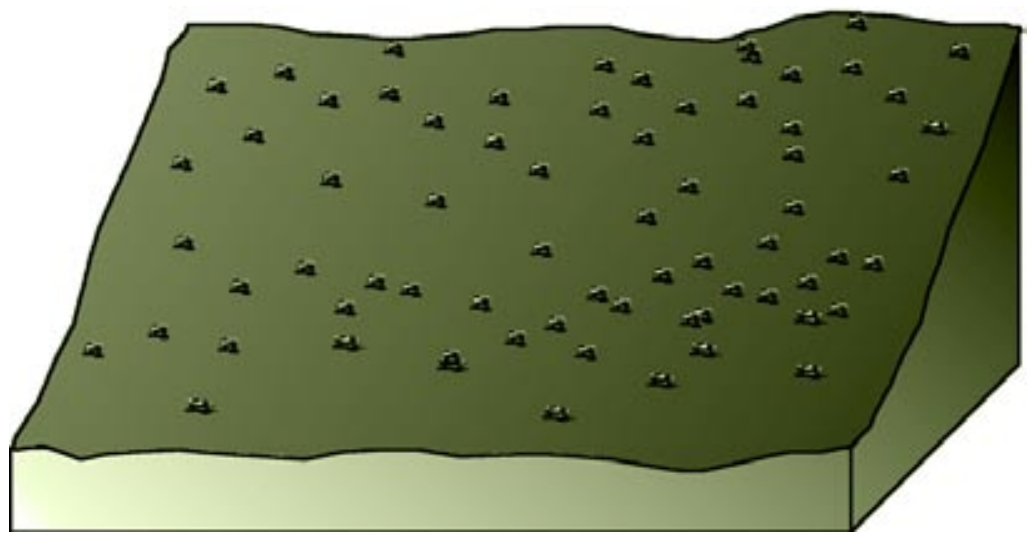

Figure 1. Clear-cut immediately after harvest. No trees are left standing.
The advantage of clear-cutting is efficiency. It is relatively easy to delineate a clear-cut block on the ground, and there is a reduced chance of damaging reserved trees. Clear-cutting is sometimes used to restore a stand to a higher level of timber productivity after a history of poor management. That is, when faced with an existing stand of low-value defective trees and undesirable species composition, a forester may decide to essentially start over by clear-cutting and planting a more desirable mix of species. Another distinct advantage of clear-cutting is that road access is limited to the immediate time of harvest and planting, after which 

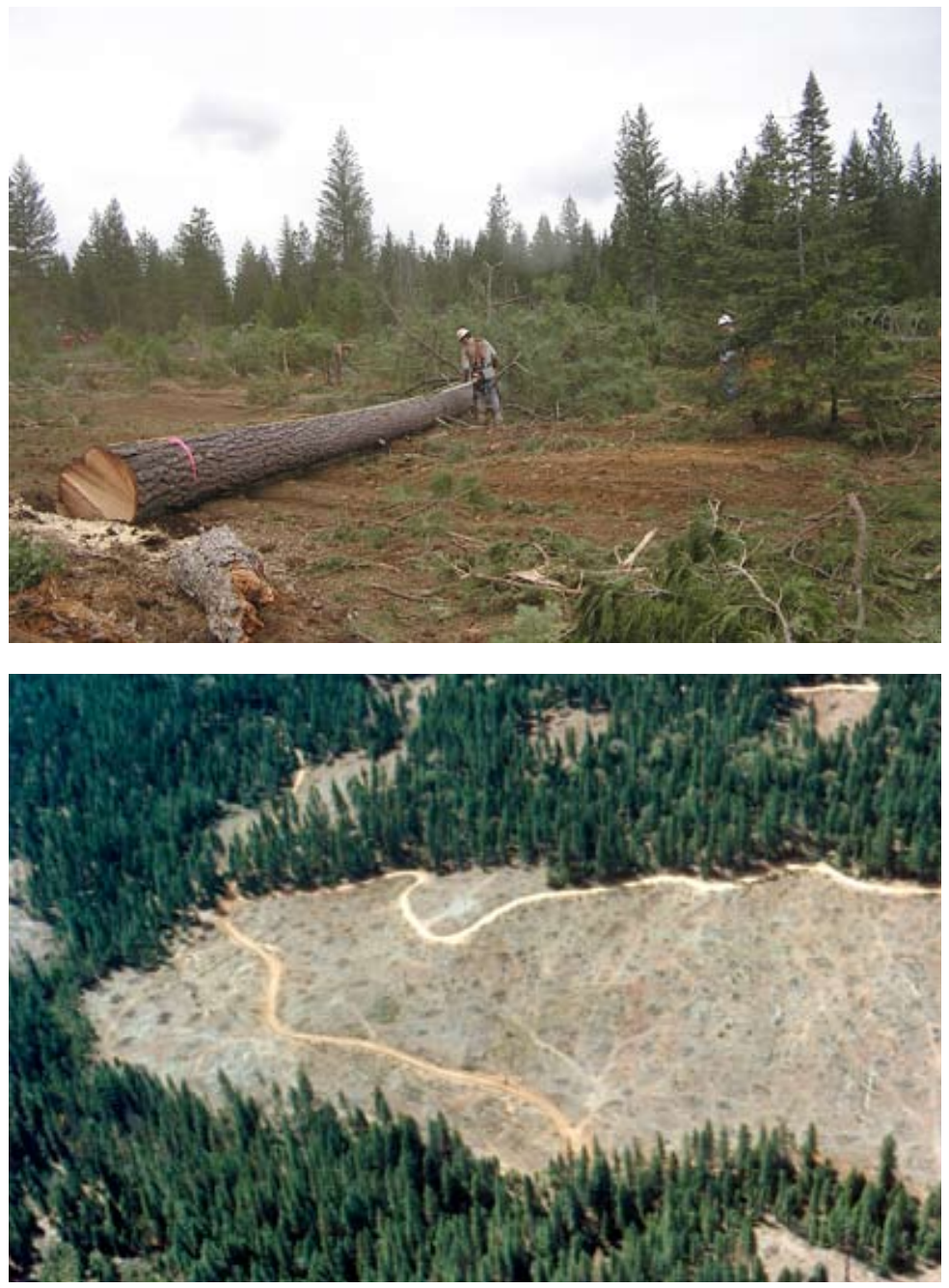

Figure 2. Sites clear-cut in conformance to today's forest practice rules from an on-the-ground and aerial viewpoints. These rules specify the maximum size of clear-cuts, require mitigation measures for stream and wildlife protection, and stipulate regeneration practices. Photos: Courtesy UC Blodgett Forest Research Station.

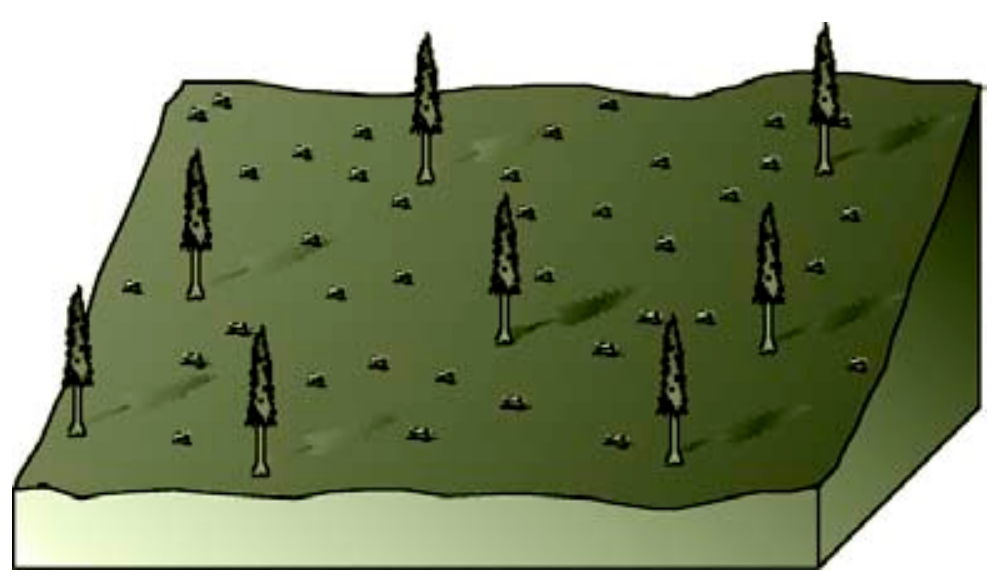

Figure 3. Seed tree selection immediately after harvest. roads may be closed until access is needed again for operations such as intermediate treatments and fire suppression. Since roads are a major source of sediment on forestland, this can be an environmental benefit.

Today's clear-cuts in California rarely resemble the clear-cuts that may have been permissible even a decade ago. Environmental restrictions specified in the California Forest Practice Rules have generally been adopted to retain islands of trees within clear-cuts, widening buffers along streams, and preserving important individual wildlife trees and snags (fig. 2).

\section{Seed tree}

The seed tree silvicultural system is an evenaged regeneration method that removes most of the stand while leaving a few desirable trees to produce seed for the next stand (figs. 3 and 4). The quality and distribution of the seed trees and the timing of the harvest are important considerations when using this system.

The seed tree system is generally used for shade-intolerant species that regenerate best in full sunlight. Site preparation is often required to remove logging debris and competing plants and to create a seedbed before the new stand becomes established.

Seed trees are usually removed not long after the regenerated trees are well established. If too much time elapses, the young trees can be damaged when the seed trees are removed. Seed tree silviculture has similar advantages and disadvantages to clear-cutting. Natural regeneration by seed trees often results in a clumpy distribution of seedlings. As they grow, thinning may be required to minimize competition and address spacing needs. Planting may be required to obtain all of the species desired or to supplement natural regeneration.

\section{Shelterwood}

The shelterwood system is often used when the species to be regenerated requires protection from direct sunlight to become established (fig. 5). Depending on the initial condition of the stand, harvesting can be done in two or three stages to regenerate the stand. The objective of the initial harvest is to improve the vigor and seed production of the remaining trees and to prepare the site for new seedlings. The reserved trees provide shade and shelter from extreme conditions (fig. 6). 


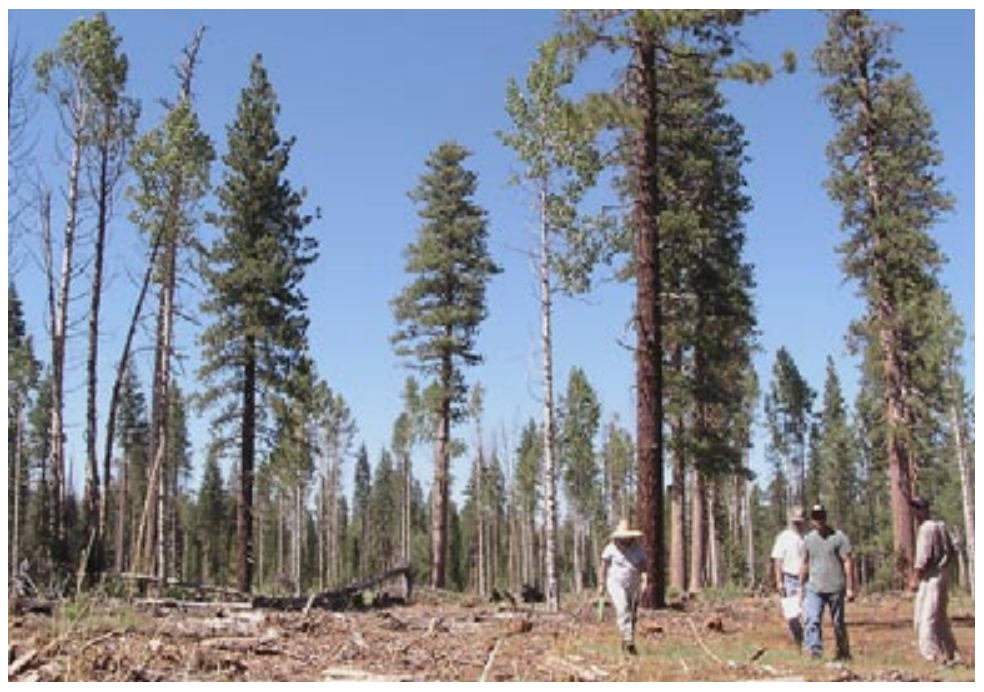

Figure 4. Site where the seed tree method was applied. Today's clear-cuts often resemble seed tree harvests because some trees must be left on a clear-cut site for wildlife habitat and other purposes. Photo: Gary Nakamura.

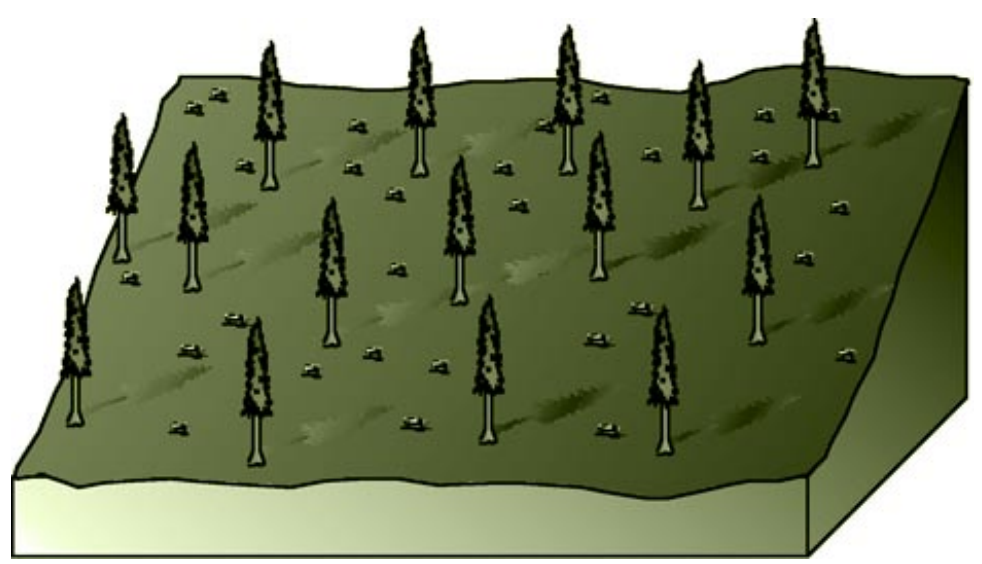

Figure 5. Shelterwood stand immediately after harvest.

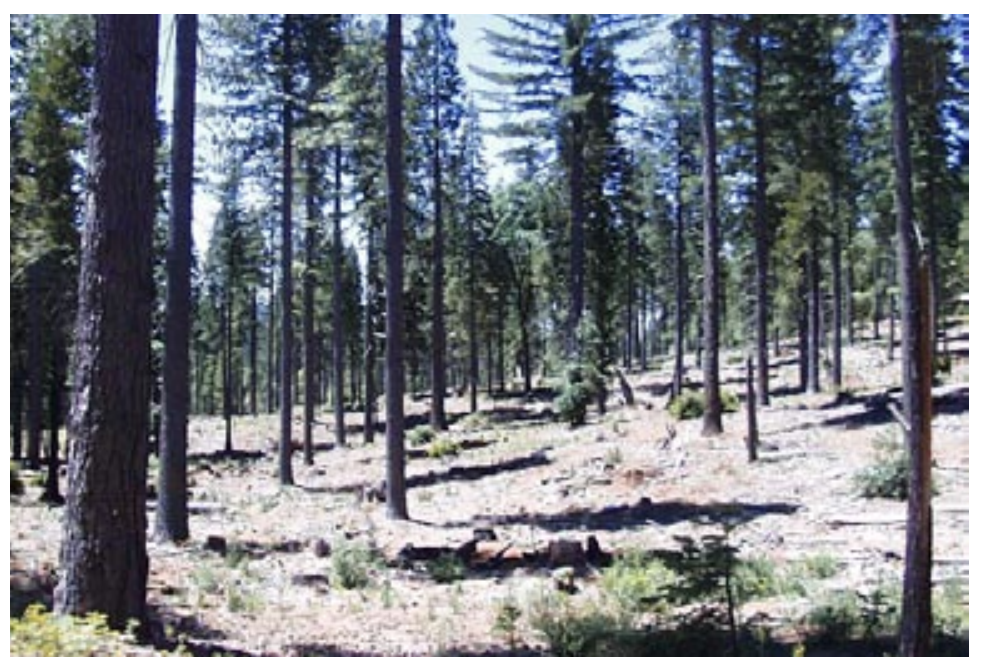

Figure 6. Shelterwood harvests are similar to seed tree harvests except that shelterwood leaves more trees standing. In either case, the remaining trees should be of good quality since they will produce the seed for the next crop. Shelterwood is often applied on harsh sites where some shade is necessary to encourage seedling establishment and survival. Photo: Courtesy UC Blodgett Forest Research Station.
Once regeneration is established, subsequent harvests remove the shelterwood trees and allow regeneration to develop an even-aged stand. The shelterwood system favors species that naturally regenerate in partial shade. Because the shelterwood trees are removed in several stages, there is less dramatic visual impact until the final harvest. As with the seed tree method, natural regeneration by shelterwood can result in a clumpy distribution of seedlings. As seedlings grow, thinning may help minimize competition. Shelterwood may be applied on harsh sites in combination with planting.

\section{Modifications to traditional systems}

In California at the present time, the traditional even-aged silvicultural systems described above are rarely used. For example, in clear-cutting, trees or groups of trees are often left standing to provide habitat for wildlife. This is sometimes termed a "partial retention" or "variable retention" harvest (fig. 7). In other cases, seed or shelterwood trees may be left standing because they contribute habitat or perform other desired functions. Most of these alterations to traditional even-aged silvicultural practices have arisen in response to concerns about impacts on wildlife, aesthetics, and water quality.

\section{Uneven-aged Management}

The main difference between an even-aged forest (fig. 8), in which numerous forest stands may have been harvested at different times and at different ages and sizes, and an uneven-aged forest is scale. That is, even-aged harvests are generally conducted on stands of up to 30 acres (about 12 ha). Uneven-aged harvests are conducted on the scale of individual trees or small groups of trees, which are usually less than a few acres in size and can be distributed over a larger area. An uneven-aged forest is comprised of trees in many age and size classes in close proximity to each other. Frequent, periodic cuttings establish and maintain this structure. The possibility that residual trees will be damaged by repeated harvesting operations requires especially careful logging operations. 


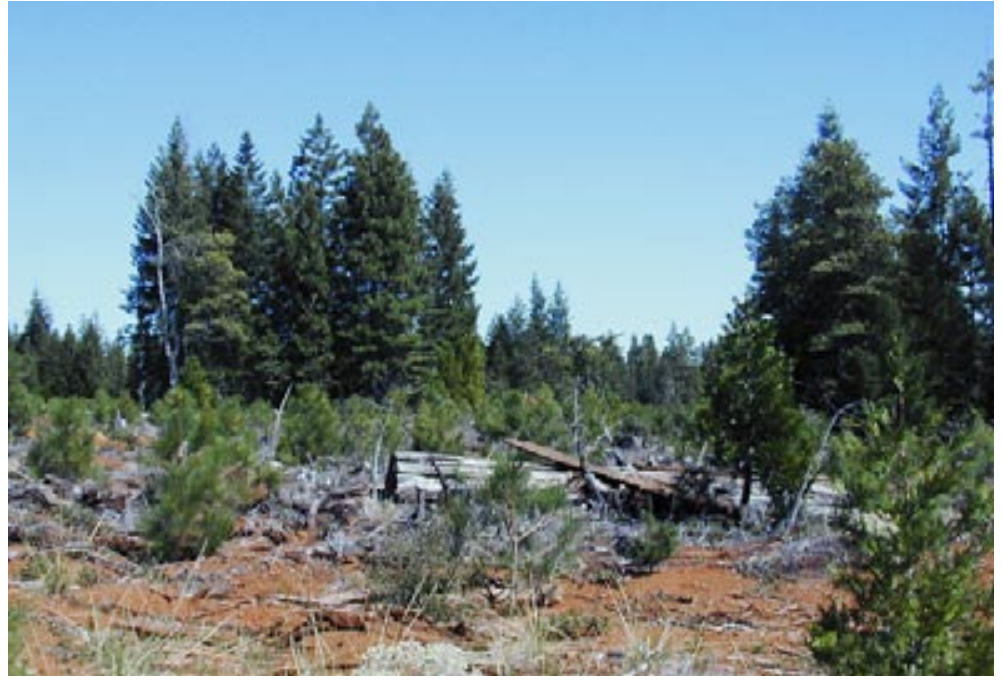

Figure 7. Variable retention harvest, showing regeneration and larger trees left for wildlife. Photo: Gary Nakamura.

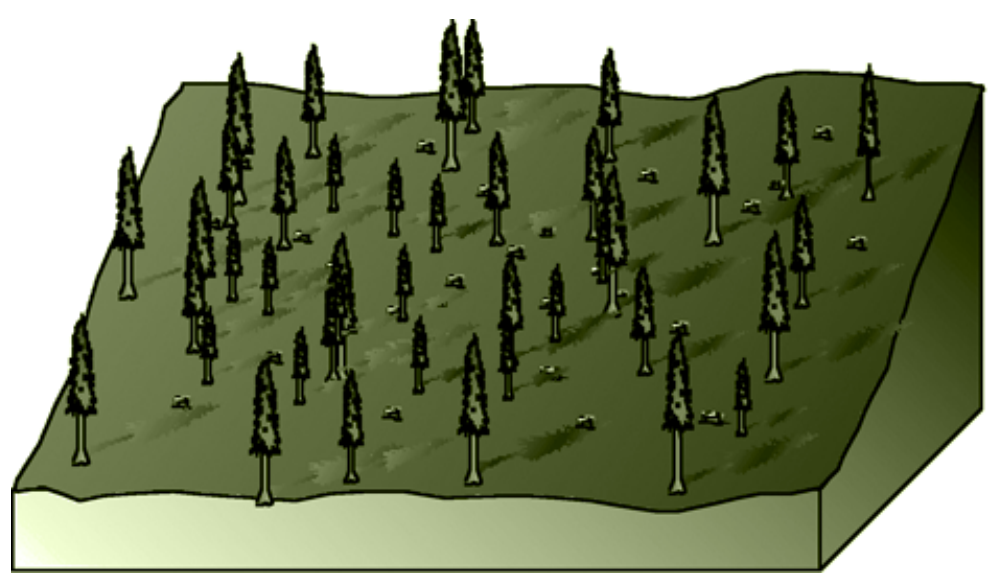

Figure 8. Uneven-aged management immediately after harvest.
Uneven-aged management has advantages and disadvantages over even-aged management. For example, because the openings in the canopies are smaller in size $(<2$ acres, or about $1 \mathrm{ha}$ ), it is assumed that impacts to wildlife with be lessoned. A potential disadvantage is that frequent harvesting requires the creation and continual maintenance of roads, and these roads are used more often (e.g., every 10 to 20 years) than in even-aged management (e.g., 30 to 80 years). Also, uneven-aged stands generally tend to be more vulnerable to crown fire. They often have diverse multistoried canopies that constitute both excellent wildlife habitat as well as combustible fuel ladders. Additionally, harvests can be more frequent, providing a more regular income stream, but they may bring a lower return per harvest.

\section{Single-tree selection}

In single-tree selection, a forester evaluates individual trees for harvest based on stand management needs and landowner objectives. Seedlings (or sprouts in the case of redwood) develop where forest canopy openings and suitable seedbeds are provided. Single-tree selection is usually applied to forest types comprised of shade-tolerant species capable of regenerating and growing in the shade of overstory trees (fig. 9).

Because of the small opening sizes, many people like the aesthetic qualities of single-tree selection, and to the untrained eye it can be difficult to know that harvesting has been done at all. Single-tree selection can provide continuous forest cover that may be of benefit to certain wildlife species. It also reduces temperatures and provides shade that can help limit invasive plant establishment and survival. The main environmental issue that must be considered is the impact of multiple entries and continual road usage. Single-tree selection is labor intensive. Marking individual trees for harvest takes considerable time, and falling and logging must be done carefully to avoid damaging the reserved trees.

Species may not reproduce equally well in a forest managed by single-tree selection. For example, in mixed Douglas-fir and coast redwood forest, single-tree selection favors the sprouting redwood rather than the less shade-tolerant Douglas-fir. Over large areas, single-tree selection can lead to reduced species diversity while increasing stand structural diversity.

If applied incorrectly, single-tree selection can lead to "high grading": harvesting the best and most valuable trees and leaving less-valuable trees behind. A primary objective of single-tree selection should be to leave the stand in a better productive condition after harvest by removing less-desirable trees, those with poor form, or those injured by insects or disease, while leaving the best trees to grow on the site. 


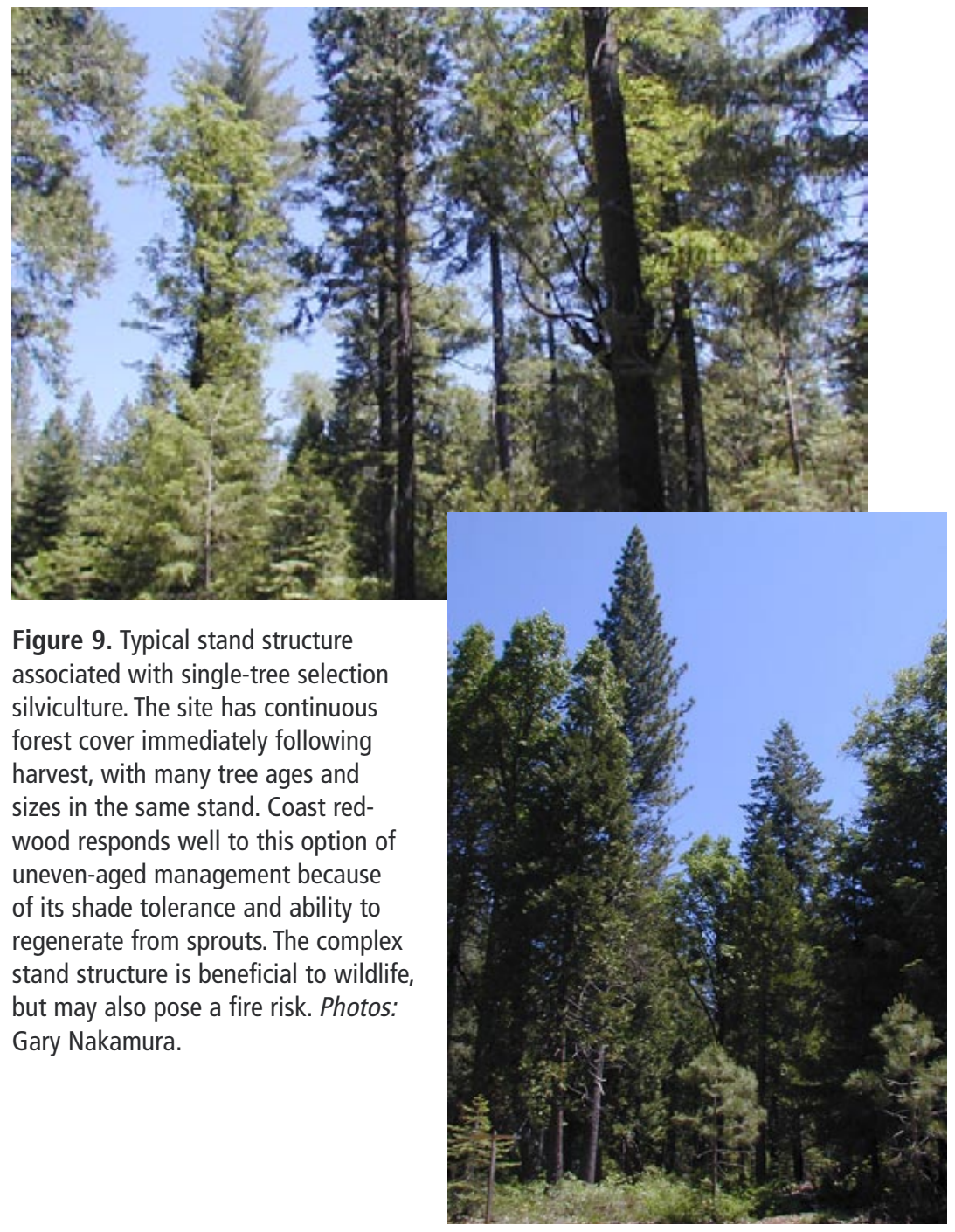

\section{Group selection}

The group selection method involves harvesting small groups rather than individual trees. The openings created resemble very small clear-cuts; in California the openings must be less than 2.5 acres in size (about 1 ha). Because the openings are small, trees on the edges typically influence the regeneration in the opening. Group selection is usually applied to forests where the dominant species are intermediate in shade tolerance. It is similar in most respects to single-tree selection, with the exception that by harvesting groups, it is somewhat easier to minimize damage to residual trees and regenerate shade-intolerant species, particularly pines. Practically speaking, most people using uneven-aged systems use a combination of single tree and group selection.

\section{Intermediate Treatments}

The purpose of an intermediate treatment is to improve the growth, quality, composition, or vigor of a stand. Unlike the regeneration goals for even- and uneven-aged systems described above, intermediate treatments are not expected to produce regeneration of new trees. Rather, they are intended to improve the survival, vigor, and growth of existing trees.

\section{Competition control}

Competition control involves removing shrub, grass, and herbaceous plants that compete with tree seedlings and saplings for moisture and light. Although most commonly associated with management of even-aged plantations, it can be used to enhance the survival of natural regeneration in an uneven-aged system. A variety of control practices are used, including selective herbicides, manual control of brush, and girdling of unwanted trees. Competition control is best applied in the first 10 to 15 years after establishment and is often used in the first 2 to 3 years after regeneration has become established.

Competition control is sometimes combined with other methods, including the use of fencing, repellents, traps, and tree shelters to prevent depredation by rodents, deer, and livestock. In some forest types, such as Douglas-fir or pine, control of animal damage is almost mandatory.

\section{Thinning}

Thinning can reduce competition between trees and accelerate growth in those trees that remain (fig. 10). In California, thinning is categorized as either commercial (removing valuable trees) or precommercial (removing trees that are too small to have commercial value). In even-aged plantations, thinning achieves the desired spacing between crop trees. Other variants of thinning include thinning dominant and codominant trees or thinning smaller trees with crowns below the dominant trees. 


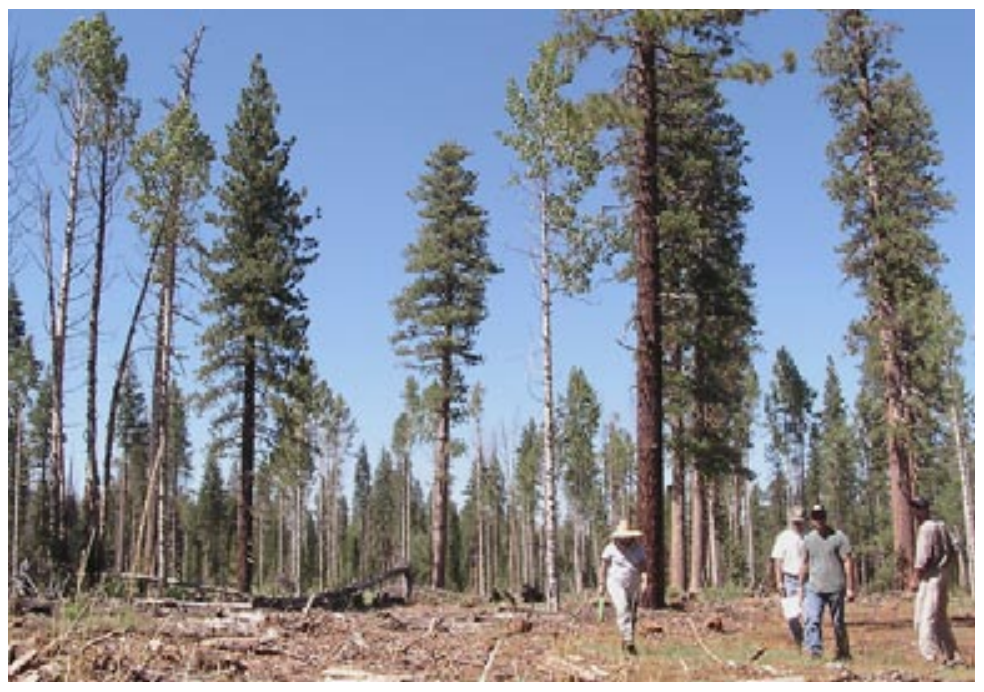

Figure 4. Site where the seed tree method was applied. Today's clear-cuts often resemble seed tree harvests because some trees must be left on a clear-cut site for wildlife habitat and other purposes. Photo: Gary Nakamura.

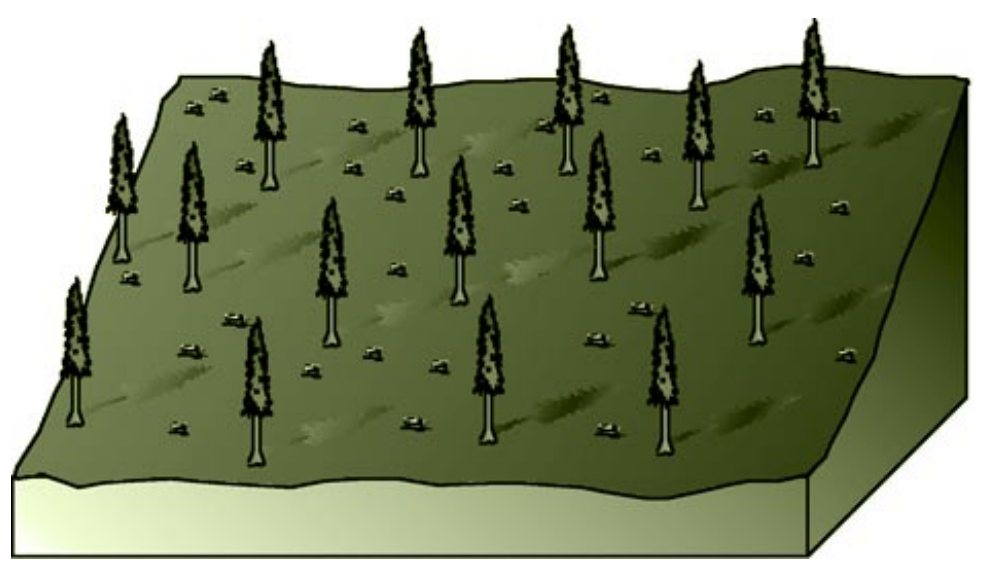

Figure 5. Shelterwood stand immediately after harvest.

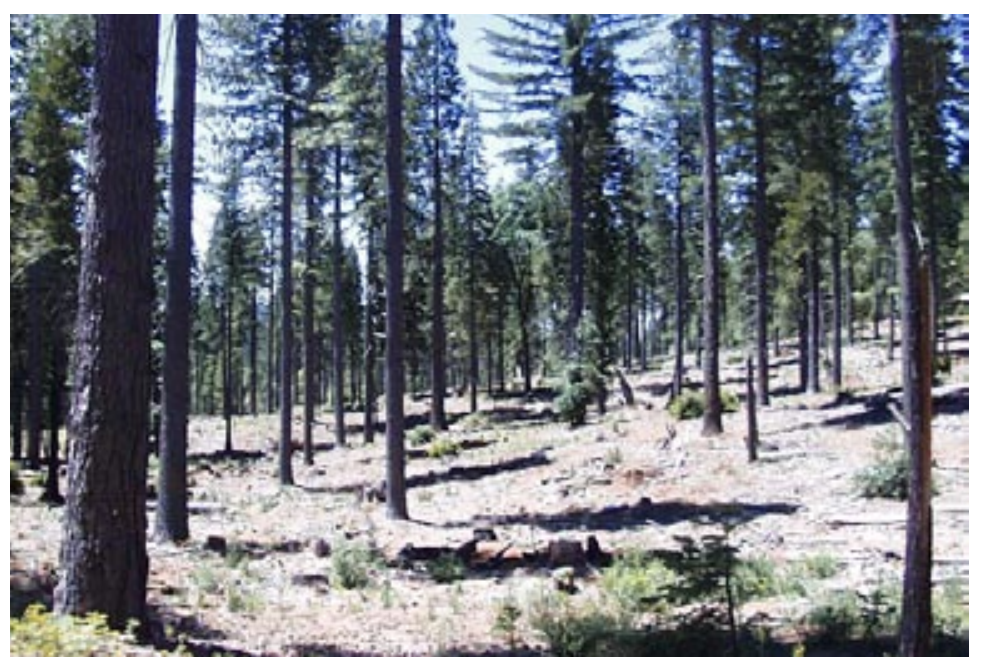

Figure 6. Shelterwood harvests are similar to seed tree harvests except that shelterwood leaves more trees standing. In either case, the remaining trees should be of good quality since they will produce the seed for the next crop. Shelterwood is often applied on harsh sites where some shade is necessary to encourage seedling establishment and survival. Photo: Courtesy UC Blodgett Forest Research Station.
Once regeneration is established, subsequent harvests remove the shelterwood trees and allow regeneration to develop an even-aged stand. The shelterwood system favors species that naturally regenerate in partial shade. Because the shelterwood trees are removed in several stages, there is less dramatic visual impact until the final harvest. As with the seed tree method, natural regeneration by shelterwood can result in a clumpy distribution of seedlings. As seedlings grow, thinning may help minimize competition. Shelterwood may be applied on harsh sites in combination with planting.

\section{Modifications to traditional systems}

In California at the present time, the traditional even-aged silvicultural systems described above are rarely used. For example, in clear-cutting, trees or groups of trees are often left standing to provide habitat for wildlife. This is sometimes termed a "partial retention" or "variable retention" harvest (fig. 7). In other cases, seed or shelterwood trees may be left standing because they contribute habitat or perform other desired functions. Most of these alterations to traditional even-aged silvicultural practices have arisen in response to concerns about impacts on wildlife, aesthetics, and water quality.

\section{Uneven-aged Management}

The main difference between an even-aged forest (fig. 8), in which numerous forest stands may have been harvested at different times and at different ages and sizes, and an uneven-aged forest is scale. That is, even-aged harvests are generally conducted on stands of up to 30 acres (about 12 ha). Uneven-aged harvests are conducted on the scale of individual trees or small groups of trees, which are usually less than a few acres in size and can be distributed over a larger area. An uneven-aged forest is comprised of trees in many age and size classes in close proximity to each other. Frequent, periodic cuttings establish and maintain this structure. The possibility that residual trees will be damaged by repeated harvesting operations requires especially careful logging operations. 


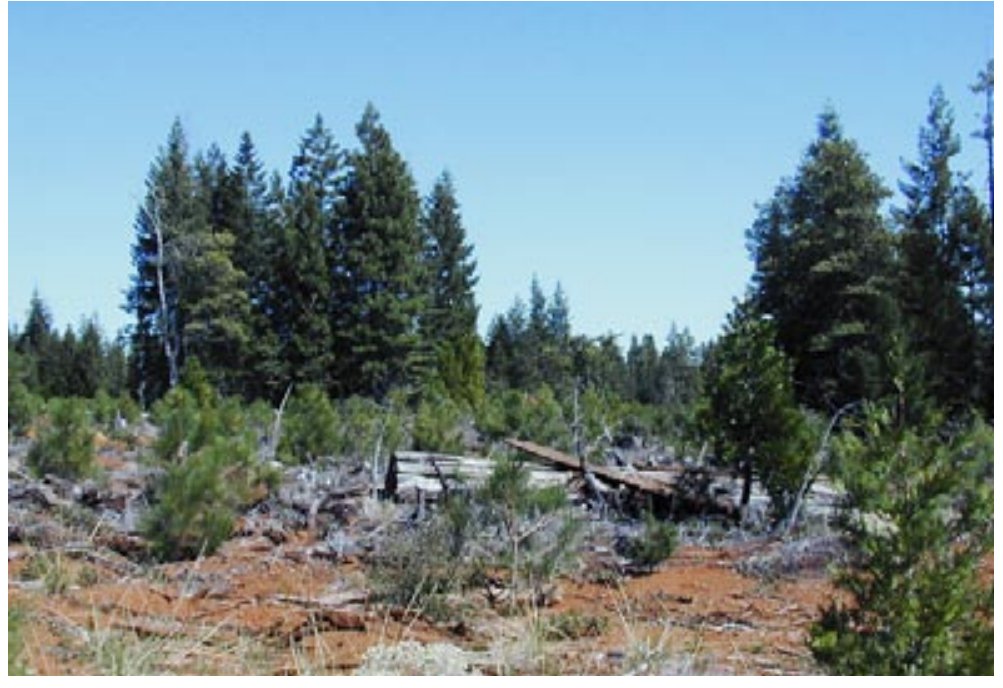

Figure 7. Variable retention harvest, showing regeneration and larger trees left for wildlife. Photo: Gary Nakamura.

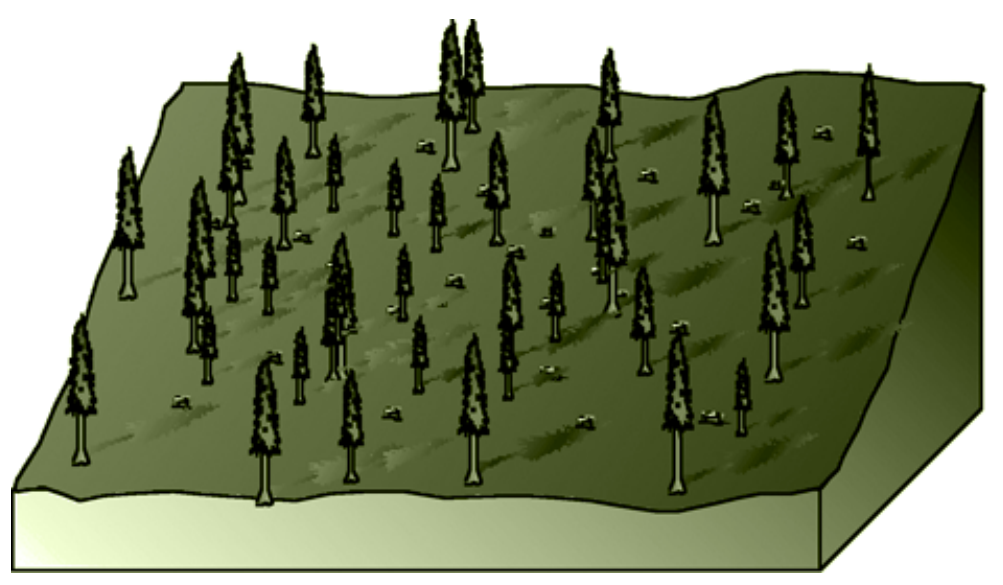

Figure 8. Uneven-aged management immediately after harvest.
Uneven-aged management has advantages and disadvantages over even-aged management. For example, because the openings in the canopies are smaller in size $(<2$ acres, or about $1 \mathrm{ha}$ ), it is assumed that impacts to wildlife with be lessoned. A potential disadvantage is that frequent harvesting requires the creation and continual maintenance of roads, and these roads are used more often (e.g., every 10 to 20 years) than in even-aged management (e.g., 30 to 80 years). Also, uneven-aged stands generally tend to be more vulnerable to crown fire. They often have diverse multistoried canopies that constitute both excellent wildlife habitat as well as combustible fuel ladders. Additionally, harvests can be more frequent, providing a more regular income stream, but they may bring a lower return per harvest.

\section{Single-tree selection}

In single-tree selection, a forester evaluates individual trees for harvest based on stand management needs and landowner objectives. Seedlings (or sprouts in the case of redwood) develop where forest canopy openings and suitable seedbeds are provided. Single-tree selection is usually applied to forest types comprised of shade-tolerant species capable of regenerating and growing in the shade of overstory trees (fig. 9).

Because of the small opening sizes, many people like the aesthetic qualities of single-tree selection, and to the untrained eye it can be difficult to know that harvesting has been done at all. Single-tree selection can provide continuous forest cover that may be of benefit to certain wildlife species. It also reduces temperatures and provides shade that can help limit invasive plant establishment and survival. The main environmental issue that must be considered is the impact of multiple entries and continual road usage. Single-tree selection is labor intensive. Marking individual trees for harvest takes considerable time, and falling and logging must be done carefully to avoid damaging the reserved trees.

Species may not reproduce equally well in a forest managed by single-tree selection. For example, in mixed Douglas-fir and coast redwood forest, single-tree selection favors the sprouting redwood rather than the less shade-tolerant Douglas-fir. Over large areas, single-tree selection can lead to reduced species diversity while increasing stand structural diversity.

If applied incorrectly, single-tree selection can lead to "high grading": harvesting the best and most valuable trees and leaving less-valuable trees behind. A primary objective of single-tree selection should be to leave the stand in a better productive condition after harvest by removing less-desirable trees, those with poor form, or those injured by insects or disease, while leaving the best trees to grow on the site. 


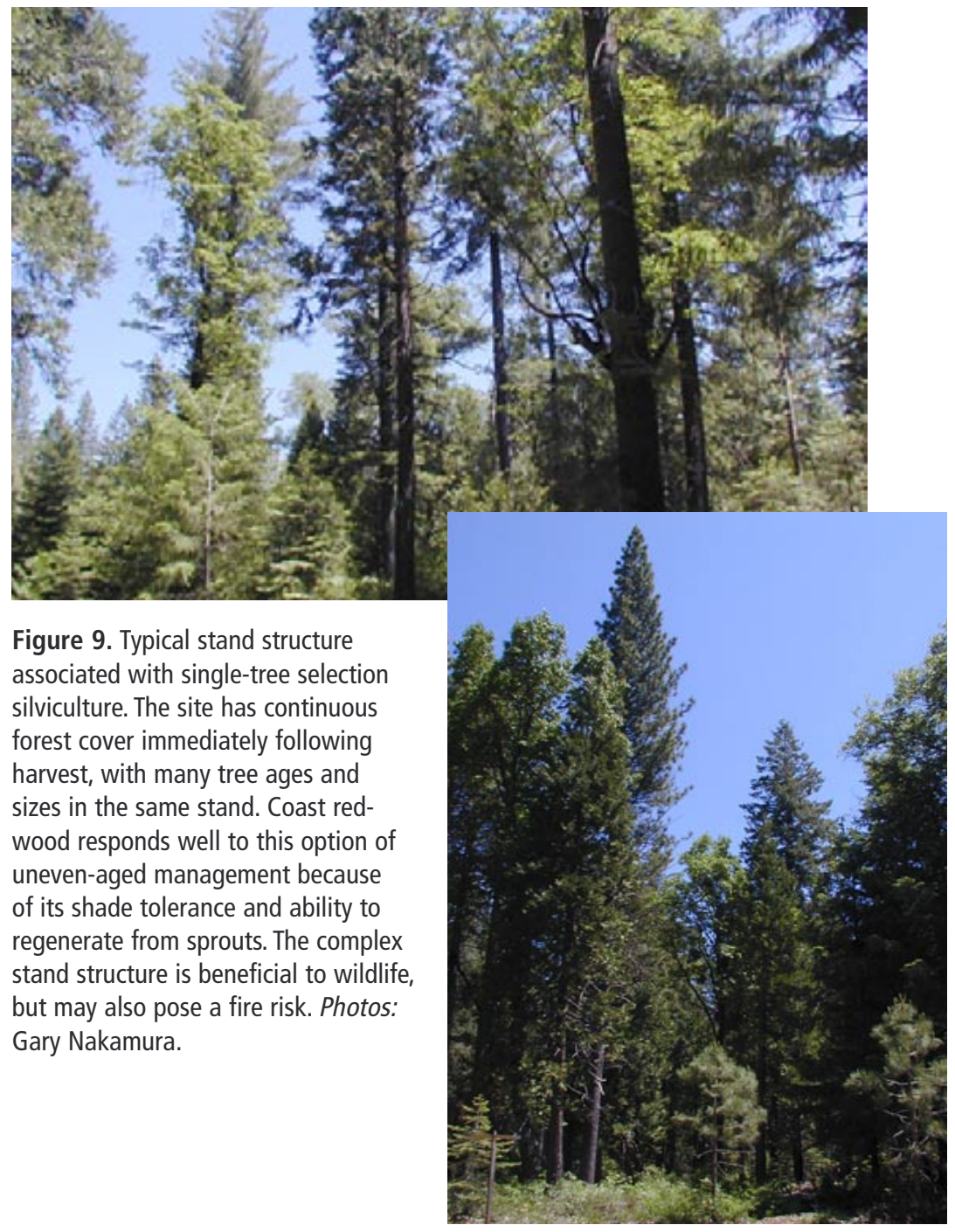

\section{Group selection}

The group selection method involves harvesting small groups rather than individual trees. The openings created resemble very small clear-cuts; in California the openings must be less than 2.5 acres in size (about 1 ha). Because the openings are small, trees on the edges typically influence the regeneration in the opening. Group selection is usually applied to forests where the dominant species are intermediate in shade tolerance. It is similar in most respects to single-tree selection, with the exception that by harvesting groups, it is somewhat easier to minimize damage to residual trees and regenerate shade-intolerant species, particularly pines. Practically speaking, most people using uneven-aged systems use a combination of single tree and group selection.

\section{Intermediate Treatments}

The purpose of an intermediate treatment is to improve the growth, quality, composition, or vigor of a stand. Unlike the regeneration goals for even- and uneven-aged systems described above, intermediate treatments are not expected to produce regeneration of new trees. Rather, they are intended to improve the survival, vigor, and growth of existing trees.

\section{Competition control}

Competition control involves removing shrub, grass, and herbaceous plants that compete with tree seedlings and saplings for moisture and light. Although most commonly associated with management of even-aged plantations, it can be used to enhance the survival of natural regeneration in an uneven-aged system. A variety of control practices are used, including selective herbicides, manual control of brush, and girdling of unwanted trees. Competition control is best applied in the first 10 to 15 years after establishment and is often used in the first 2 to 3 years after regeneration has become established.

Competition control is sometimes combined with other methods, including the use of fencing, repellents, traps, and tree shelters to prevent depredation by rodents, deer, and livestock. In some forest types, such as Douglas-fir or pine, control of animal damage is almost mandatory.

\section{Thinning}

Thinning can reduce competition between trees and accelerate growth in those trees that remain (fig. 10). In California, thinning is categorized as either commercial (removing valuable trees) or precommercial (removing trees that are too small to have commercial value). In even-aged plantations, thinning achieves the desired spacing between crop trees. Other variants of thinning include thinning dominant and codominant trees or thinning smaller trees with crowns below the dominant trees. 

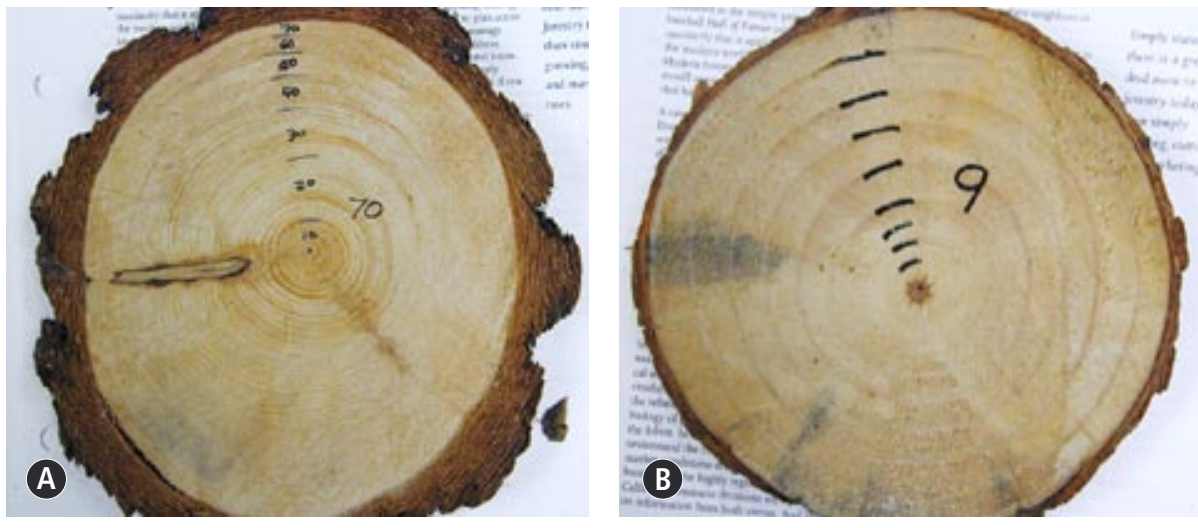

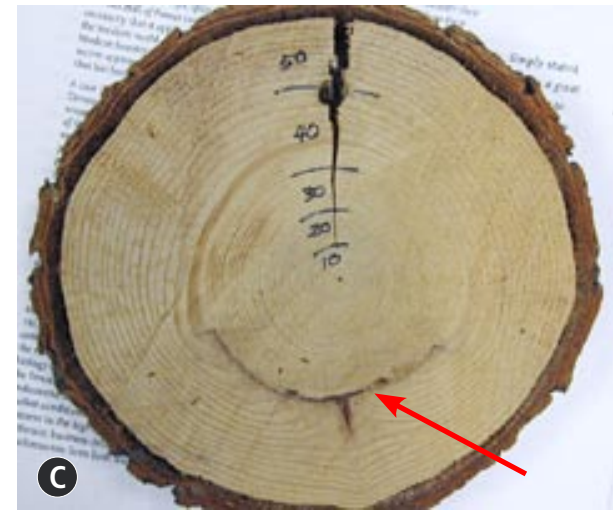

Figure 10. Effects of competition on diameter growth. All the crosssections are 6 inches $(15 \mathrm{~cm})$ in diameter. Figure $9 A$ is ponderosa pine, 70 years old, growing under high competition for moisture, light, and nutrients at 1,000 trees per acre (2,470 per ha); diameter growth and ring width slow with age. Figure $9 \mathrm{~B}$ is ponderosa pine, 9 years old, growing under low competition of 300 trees per acre (740 per ha); diameter growth has been accelerating. Figure $9 \mathrm{C}$ is white fir, 50 years old, growing under competition the first 30 years (the inner 30 rings). Twenty years ago, this tree was damaged by a harvest that removed the competing trees around it, releasing it to grow more quickly. Note the scar from logging damage. Photos: Gary Nakamura.

The obvious question is, how do you select which trees to take or leave? The answer depends on the species in question, management objectives, and site conditions, among other factors. Rules of thumb in thinning include the following.

- The first thinning should be done early in the life of a stand, before the competition begins to severely limit stand growth. Generally, precommercial thinning of plantations is done in the first 10 to 15 years and is repeated one or more times until the trees reach a merchantable size.

- In the first thinning, trees that demonstrate the best growth (height) should be retained. A later thinning is often done when tree crowns begin to touch. This later thinning is based on a spacing that allows for crown expansion until the next thinning will occur.

- In some cases, thinning is coupled with limb pruning to improve the quality of wood produced by minimizing knots. Care must be exercised to not overprune so that crop trees have relatively full crowns to maximize growth.

- Trees with less than one-third of their total height in live branches rarely respond well to thinning.

- Trees with poor form or showing evidence of damage, insects, or disease are usually removed.

- Later precommercial and commercial thinning is intended to increase diameter growth on residual trees by providing adequate growing space. Thinning should not be confused with uneven-aged management, in which the goal is regeneration to create a balanced distribution of tree sizes. Commercial thinning is generally associated with even-aged management as a way to capture the value of mortality until the stand matures.

Especially in stands that are naturally regenerated, thinning can improve stand composition and favor the most desirable species. The choice of species depends on the landowner's objectives for timber, wildlife, aesthetic appeal, or recreation. Many trees that have little to no timber value might be reserved to favor these other purposes.

One way to gauge the health of a tree is to look at its crown ratio, the percentage of the total height of the tree that is in live branches (fig. 11). Dominant trees have about a 50 percent crown ratio; codominants, about 40 percent; intermediates, about 30 percent; and suppressed trees, about 20 percent. Open-grown "wolf" trees have a crown ratio of about 80 percent. Larger crown ratios mean that a tree can capture more 
sunlight and produce more food. Once a tree has less than a 33 percent crown ratio, it usually cannot be released from competition. Trees with low crown ratios are more susceptible to insect attacks.

Wolf trees use up too much space for timber production goals. But as they die and decompose, wolf trees can make excellent snags for wildlife. Some species, such as white fir, can survive as suppressed trees and can respond if surrounding trees are removed. Others, such as ponderosa pine, do not survive well as suppressed trees and will not respond consistently to thinning.

\section{Sanitation and salvage}

Sanitation is the removal of insect-attacked, diseased, or damaged trees in order to maintain or improve the overall health of the stand. Natural events such as fire, windstorms, and ice storms may kill or break trees in a forest. Salvage is the removal of only trees that are dead, dying, or deteriorating because of damage from fire, wind, insects, disease, flood, or other causes. Salvage provides for the economic recovery of trees before the total loss of their wood product value. Sanitation and salvage may be combined into a single operation. Sanitation-salvage harvests are exempt from filing a timber harvest plan if they harvest less than 10 percent of the forest volume per acre.

\section{ACHIEVING YOUR GOALS}

The silvicultural methods you choose for your property depend in large part on your goals. Clearly defined goals and objectives help you create the forest structures that meet your needs. Your registered professional forester can help you decide which silvicultural systems are most appropriate. Often, the actual prescription for a property will be a blend of treatments. The more clearly you can define and describe your goals and objectives, the more likely it is that you will be satisfied with your forest after the harvest.

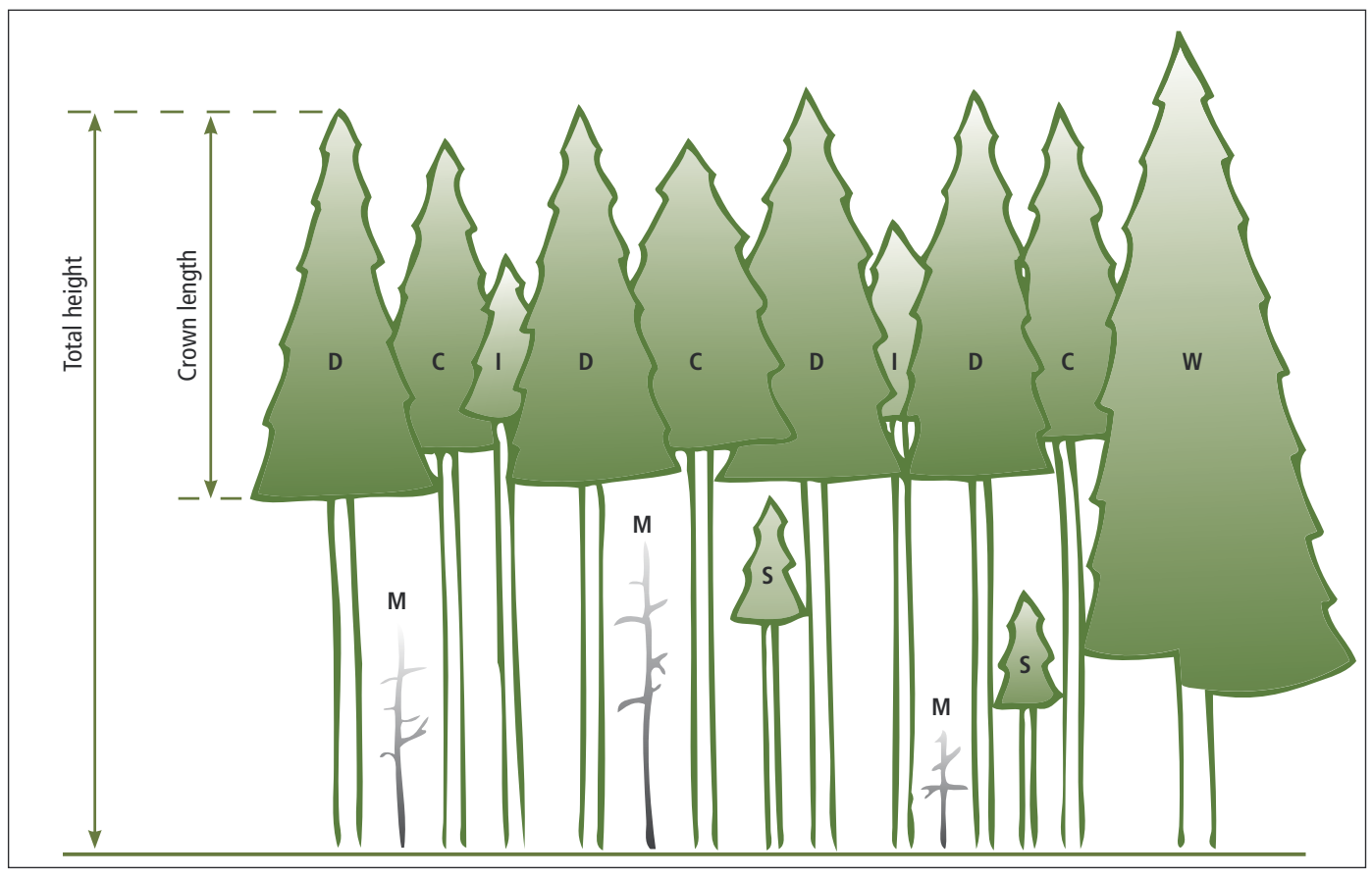

Figure 11. Effects of competition within a stand. Key: $C=$ codominant, $D=$ dominant, $I=$ intermediate, $\mathrm{M}=$ mortality, $\mathrm{S}=$ suppressed, $\mathrm{W}=$ wolf tree. 


\section{Restoration}

Many landowners state that restoration is an important goal. Does this mean restoration to a healthier condition? To a forest that contains a certain kind of wildlife habitat? To a pre-European-settlement forest condition? To a forest that does not contain exotic species? The better you can define restoration the better you will be able to meet your goals.

\section{Forestry restoration}

If you have lands that have been heavily cut, your restoration goal might be to establish a healthy, mature forest. One way to do this is through a series of selection cuts or thinnings that allow the trees to increase in size, improving stand structure.

\section{Riparian restoration}

Restoring riparian areas could include a number of overlapping projects. Some might focus on keeping stream temperature down by planting trees to provide shade; these trees can also help improve bank stability. In some cases, you might put large woody debris or large rocks in strategic locations to protect banks from erosion or to help create pools for fish. Bioengineering projects using living material, such as willows, can stabilize stream banks and filter sediment.

\section{Erosion control}

Projects to reduce erosion often focus on getting water back into natural streams. Water can be diverted by roads or skid trails. Erosion can also occur on areas denuded of vegetation.

\section{Oak woodland restoration}

Restoring oak woodlands could include projects such as preventing or controlling conifer encroachment as well as planting oaks.

\section{Control of exotics}

You may want to reduce or eliminate species that are not native, such as starthistle or broom, on your entire property or only on a portion of it.

\section{Wildlife habitat enhancement}

You can encourage certain species (such as deer and elk) or a type of animal (waterfowl) to use your land, or discourage certain species, for ecological or personal reasons. You can do this through managing elements such as the habitat, the kinds of trees and shrubs in the forest, and the availability of snags, downed woody debris, and year-round water. To start with, you need to know which species you are managing for and their habitat requirements. It is not possible to manage for every species on every acre, as each wildlife species requires different habitat needs.

\section{Recovery after wildfire}

Restoration after a fire could include planting trees, spreading grass seed, and erosion control, confirming that drainage structures are intact and evaluating burned trees for the likelihood of survival.

\section{Fuel Reduction}

Consider removing understory shrub and suppressed trees, and limbing trees to eliminate fuel ladders that could carry a fire into the crowns of the green overstory trees.

\section{Planning}

Whatever your restoration goals, you will want to develop a plan for meeting them. Your Registered Professional Forester will be able to help you define your goals and get you thinking about what to cover in your plan. They should also have contacts with local agency representatives and be able to recommend contacts for more information. 
Plans for restoration work range from the very simple ("I just want to get this darned starthistle out!") to detailed plans that outline decades-long strategies for creating, restoring, and maintaining desired conditions.

\section{RESOURCES}

\section{Public Agencies}

Several public agencies can offer information or assistance on vegetation management issues and restoration.

California Department of Fish and Game (DFG). A state agency that manages California's wetlands, wildlife habitats, and ecosystems. See the DFG Web site at http://www.dfg.ca.gov.

California Department of Forestry and Fire Protection(CAL FIRE). A state agency that provides fire protection and a multitude of fire-related and natural resource management services on state lands. Local units can be reached under the State Government listings in a telephone directory or at the CAL FIRE Web site, http://www.fire.ca.gov.

Forest Stewardship Helpline. This service is provided under the USDA Forest Stewardship Program to provide information and referral to landowners, resource professionals, and others. The Helpline is an excellent information clearinghouse that answers questions about forest management including what to do, whom to call, and where to go for more information. Call toll-free at 1-800-738-8733 or e-mail ncsaf@mcn.org. The Forest Stewardship Program Web site can be found at http://www.fs.fed.us/spf/coop/programs/loa/fsp.shtml.

Natural Resources Conservation Service (NRCS). A federal agency with special expertise in soils that also administers federal cost-share programs such as the Environmental Quality Incentives Program (EQIP), with funding for forestryrelated projects. See their Web site at www.nrcs.usda.gov.

UC Cooperative Extension (UCCE). The University of California offers an extensive network of agricultural and natural resource services and information on many topics including pest management, animal and plant production, and natural resource management. Your local UCCE office can be found in the business listings in a telephone directory or at the UCCE statewide directory, http://www.ucanr.org.

U.S. Fish and Wildlife Service (FWS). This federal agency may be helpful when seeking information about wildlife habitats and endangered species environments; see their Web site at http://www.fws.gov/.

\section{Restoration Funding Sources}

A number of California state and federal grant programs encourage various kinds of restoration projects on private lands. Some programs are available to individual landowners, and some to larger ownerships. Funding sources change from year to year, so it is a good idea to check periodically to see what is available.

In some cases, funding is made available only to groups. You may qualify for such funds in several ways: as part of a watershed group, as a homeowners' association, as a local Fire Safe Council, and so on. Again, your forester or public agency representative may be able to help you navigate the maze of requirements and show you how to qualify for a program appropriate to your needs. 
Most counties in the state have a resource conservation district (RCD), many of which now have watershed coordinators who can help you. The focus of each RCD is different, but all focus on the management of local natural resources. Typically, members of RCD boards are local natural resource managers from the public and private sector as well as private landowners and other interested individuals. RCDs sometimes have existing grants that you as an individual landowner can apply for. It is worth a call to your local RCD to see if they have any ongoing projects you might become involved in. For more information, visit the Resource Conservation District Watershed Information Sharing Project Web site, http://www.carcd.org/wisp.

\section{FOR FURTHER INFORMATION}

To order or obtain printed ANR publications and other products, visit the ANR Communication Services online catalog at http://anrcatalog.ucdavis.edu. You can also place orders by mail, phone, or FAX, or request a printed catalog of our products from:

University of California

Agriculture and Natural Resources

Communication Services

6701 San Pablo Avenue, 2nd Floor

Oakland, California 94608-1239

Telephone: (800) 994-8849 or (510) 642-2431

FAX: (510) 643-5470

E-mail inquiries: danrcs@ucdavis.edu

An electronic version of this publication is available on the ANR Communication Services Web site at http://anrcatalog.ucdavis.edu.

Publication 8236

ISBN-13: 978-1-60107-456-0

(c) 2007 by the Regents of the University of California, Division of Agriculture and Natural Resources. All rights reserved.

The University of California prohibits discrimination or harassment of any person on the basis of race, color, national origin, religion, sex, gender identity, pregnancy (including childbirth, and medical conditions related to pregnancy or childbirth), physical or mental disability, medical condition (cancer-related or genetic characteristics), ancestry, marital status, age, sexual orientation, citizenship, or status as a covered veteran (covered veterans are special disabled veterans, recently separated veterans, Vietnam era veterans, or any other veterans who served on active duty during a war or in a campaign or expedition for which a campaign badge has been authorized) in any of its programs or activities. University policy is intended to be consistent with the provisions of applicable State and Federal laws.

Inquiries regarding the University's nondiscrimination policies may be directed to the Affirmative Action/Staff Personnel Services Director, University of California, Agriculture and Natural Resources, 300 Lakeside Drive, 6th Floor, Oakland, CA 94612-3550 (510) 987-0096. For a free catalog of other publications, call (800) 994-8849. For help downloading this publication, call (530) 297-4445.

This publication has been anonymously peer reviewed for technical accuracy by University of California scientists and other qualified professionals. This review process was managed by the ANR Associate Editor for Natural Resources.

pr-12/07-SB/RW 